\title{
LXXVIII. Reply to Mr. M.'s Remarks on Mr. Smyth's comparative table in vol. Xxxv. p. 488
}

\author{
Mr. Smyth
}

To cite this article: Mr. Smyth (1810) LXXVIII. Reply to Mr. M.'s Remarks on Mr. Smyth's comparative table in vol. xxxv. p. 488, Philosophical Magazine Series 1, 36:152, 435-437, DOI: $10.1080 / 14786441008563221$

To link to this article: http://dx.doi.org/10.1080/14786441008563221

曲 Published online: 18 May 2009.

Submit your article to this journal \lceil

Џ Article views: 2

Q View related articles $\sqsubset$ 
LXXVIII. Reply to Mr. M.'s Remarks on Mr. Smyth's Compurative Taule in vol, xxxv. p. 488. By Mr. SMrTH.

To Mr. Tilloch:

SIR, I shatí esteem it a favour if you will insert the following answer to the gentleman who signs himself $M$. in your Magazine for September.

Mr. M. says it is "curious that Mr. S. should presume organ-tuners will continue to tune as their ancestors did before them, till irrefragable arguments are produced to prove the superiority of Kirnberger's temperament."' Here, I confess, I stand convicted of inconclusive reasoning. The fact, however, I imagine to be this: an organ, with compound stops, will not admit of the major thirds being tuned sufficiently sharp to ameliorate, in any considerable degree, those greatly tempered chords which are called wolves; of which I wish the breed were extinct.

1 am glad to find that Mr. M. agrees with me in opinion, that Kirnberger's is one of the worst unequal temperaments. Had Mr. M. stated in definite terms his own favourite system, it should have been submitted to examination.

Mr. M. says, "perhaps for the organ a good unequal temperament is preferable to the Isotonic." I was not ignorant that even for this instrument the Isotonic has had its advocates; and Mr. M. presents to my view the names of Couperin, Marpury, Rameau, Cavallo, professor Chladui, and many other eminent philosophers. Now, not being a philosopher myself, I take the liberty of asking one plain question, which relates solely to the temperament of the organ :-Can any man living prove, that there ever was one organ in Christendom tuned according to the equal temperument, in cousequence of a peremptory order from any one of these gentlemen, and suffered to remain in that state ? This is coming to the point.

A person disposed to cavil might raise arithmetical and philosophical doubts whether a real equal temperament has ever been heard.

I wish Mr. M. would inform us, and explain precisely, what the system is which he tunes so dexterously on his harp, by the melody alone, without striking consonances. Had his instrument so tuned been intended for melody alone, this mode of tuning might answer the purpose; but, as each of the strings has various relations to other strings, and a temperament of a diatnnic interval, too small to pro$2 \mathrm{E} 2$ duce 
duce a seusible effect in melodv, will produce a very sensible effect in harmony, I congratulate Mr. M. upon a power which I never had the felicity of seeing exercised by any one person.

Never having heard of such a writer as Eximeno, I referred to Dr. Burney's History of Music, and there learn that Eximeno was possessed of eloquence, fire, and a lively imagination; but that his book has been called, in Italy, "a whimsical romance upon the art of music, in which he discovered a rage for pulling down, without the power of rebuilding."

1 have annexed, in compliance with Mr. M.'s request, the beats of mean tone temperament in one second. I need not add that, by taking the first decimal, the beats will be obtained for ten seconds, which I would recommend. I have also subjoined the beats of Mr. Marsh's System; and wish to be informed by that gentleman if he has had an organ tuned according to this system.

Persons unacquainted with the theory of the beatings of imperfect (that is, tempered) consonances, may object to a table of beats, that so large a number as 80 or 50 in ten seconds cannot be counted. For the information of these gentlemen, I add, that no one can count these beats : in fact, they rather howl than beat; but they vecessarily result from the temperament of the slowly beating consinances by which the temperament is laid.

I remain, Mr. Editor,

Norwich, Deč. 5, 1810. Yours, \&c.

C. J. SмYTII.

P. S.-Please to correct an erratum in my paper, p. 250, second line from the bottom, for policity read policy.

Mean Tone Trumerament.

Beats in one second.

\begin{tabular}{|c|c|c|c|c|c|c|c|}
\hline C & 480 & 3. & III. & 4 & $V_{t}$ & 6. & VI. \\
\hline B & 448.6065 & $8 \cdot 366$ & $53 \cdot 8099$ & 5.5740 & 4.1755 & 0 & 6.9675 \\
\hline Bb & $429 \cdot 3227$ & $68 \cdot 1522$ & $G$ & 5.0410 & 3.6793 & 80.4716 & 6.6593 \\
\hline A & $401 \cdot 2438$ & 7.4628 & 0 & 4.9886 & $3 \cdot 731$ & 0 & $6 \cdot 170$ \\
\hline$*$ & 37.5 & 6.9675 & 4.5 & $4 \cdot 6704$ & $23 \cdot 4212$ & 0 & 40.9838 \\
\hline G & 358.8838 & 6.6883 & 0 & $4 \cdot 4648$ & & 0 & 5.5310 \\
\hline * & 335.4110 & 6.2470 & 40.2358 & $4 \cdot 1.55$ & 3.1194 & 0 & 455764 \\
\hline F & $320-9972$ & $50 \cdot 9832$ & 0 & $3 \cdot 47$ & & $60 \cdot 19: 6$ & $4.9870^{\circ}$ \\
\hline $\mathbf{E}$ & 300. & 5.5810 & 0 & 3.7314 & 2.7870 & 0 & $4 \cdot 6704$ \\
\hline $\mathrm{Eb}$ & $287 \cdot 1053$ & 45.5768 & 0 & $23 \cdot 4,122$ & & $53 \cdot 8099$ & 4.4735 \\
\hline D & $268-3273$ & 4.9878 & 0 & $3 \cdot 3+22$ & $2 \cdot+9 \cdot 13$ & 0 & $4 \cdot 1830$ \\
\hline & 250.7784 & $4 \cdot 6704$ & $30 \cdot 0968$ & $3 \cdot 1194$ & & 0 & 34.0761 \\
\hline C & 240. & 4.4795 & 0 & $2 \cdot 9916$ & $2 \cdot 2424$ & 45 & $3 \cdot 7314$ \\
\hline
\end{tabular}


Mr. Marsh's Srstem.

Beats in one Second.

\begin{tabular}{|c|c|c|c|c|c|c|c|}
\hline $\mathrm{C}$ & 480 & 3. & III. & 4. & V & 6. & VI. \\
\hline B & $451 \cdot 3838$ & $18 \cdot 3838$ & $31 \cdot 4802$ & $2 ., 3800$ & $2 \cdot 5306$ & $17 \cdot 7984$ & 15.4250 \\
\hline $\mathbf{B b}$ & 48.2557 & 40.0412 & 10.6067 & 3.3066 & 2.4007 & $47 \cdot 0736$ & 147447 \\
\hline $\mathbf{A}$ & 402.7338 & 16.4028 & $9 \cdot 9784$ & 30162 & 2.2478 & 15.8794 & $19.76 \div 2$ \\
\hline$*$ & $378 \cdot 7240$ & $15 \cdot 4250$ & $26 \cdot 381 \cdot 0$ & 2.8758 & 8.0076 & 14.9330 & $29 \cdot 9746$ \\
\hline$G$ & 359.9272 & 14.7447 & 8.8992 & 2.6912 & $2.01+0$ & $14 \cdot 1686$ & $12 \cdot 2794$ \\
\hline 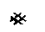 & $337 \cdot 9052$ & $13 \cdot 76 \div 2$ & $23 \cdot 5368$ & 2.5306 & $1 \cdot 8994$ & 13.3226 & $26 \cdot 7434$ \\
\hline$E$ & 3205991 & 99.9746 & 7.9397 & $2-4006$ & 1.7975 & $3 \pi .2398$ & 10.9559 \\
\hline$E$ & $501 \cdot 4859$ & 12.2794 & $7 \cdot 4665$ & 8.2478 & 1.6901 & 11.8872 & $10 \cdot 3023$ \\
\hline Eb & $286 \cdot 0449$ & $26 \cdot 7434$ & $7 \cdot 0 \times 43$ & $8 \cdot(1076$ & 1.6053 & 31.4802 & 9.7755 \\
\hline$D$ & $268 \cdot 99 ! 9$ & $10 \cdot 9559$ & 6.6613 & $2 \cdot \div 140$ & i. 5081 & $10 \cdot 6067$ & $9 \cdot 1919$ \\
\hline$*$ & 252.9553 & 10) 3093 & 17.3199 & $i \cdot r i 944$ & 1.4379 & 9.9734 & $20-0206$ \\
\hline$\ddot{\mathbf{C}}$ & 240 & $9 \cdot 7755$ & 0.9436 & 1.7973 & 1.34 .36 & $26+3800$ & $8 \cdot 2014$ \\
\hline
\end{tabular}

LXXIX. Copy of the Instructions given to their Engineers by the Commissioners appointed to ingnire into the Nature and Extent of the severul bogs in Ireland; with further Particulars respecting the Bog of Allen, and its Substrata; accompanied with a tranverse Seciton of Lullymore Bog, reduced from Mr Griffith's Slueet Section. By Mr. William Fatiet.

$\Gamma_{\text {ue secretary of the commissioners appointed to inquire }}$ into the nature and extent of the several Bugs in Treland, and the practicability of draining and cultivating them, is directed by the Board to communicate, for the information of the engineers who mav be employed, and of the proprietors of bogs, the mode in which they have been advised to proceed.

"1 1st. - They propose to divide the Bogs of Ireland into districts, and to assign each district in charge to one or more engineers.

"2d.-Each of the engineers is to provide a sufficient number of assistants, for whose qualifications he is to be responsible.

" $3 \mathrm{~d}$.- The commissioners think it necessary to direct the attention of their engineers to the particular heads of inquiry contained in these instructions; but it is by no means intended to contine their judgement within these limits; on the contrary, where local circumstances point out a preferable mode of proceeding, the commissioners expect that it shall be fully stated, in addition to the information on the different points which they now suggest.

"4th.-They conceive, that the first steps twwards the dıainage of an extensive bog, should be to ascertain the $2 \mathrm{E} 3$ 